\title{
Eccrine Porocarcinoma: Clinical and Pathological Report of Eight Cases
}

\author{
Yuta Kurashige Tokuya Minemura Tetsuo Nagatani \\ Department of Dermatology, Hachioji Medical Center, Tokyo Medical University, \\ Tokyo, Japan
}

\section{Key Words}

Clinical findings · Eccrine porocarcinoma $\cdot$ Histopathology $\cdot$ Immunohistochemistry

Prognostic factor

\begin{abstract}
Background: Eccrine porocarcinoma (EPC), a slow-growing carcinoma of the sweat gland, is a rare condition documented only in a small number of case series. Due to its rarity, guidelines and specific recommendations are not widely available. Accordingly, many dermatologists encounter difficulty in diagnosing and treating EPC. The aim of this study is to report the clinical and pathological features of EPC in order to contribute to the body of information currently available on the subject. Patients and Methods: From 2003 to 2013, 8 Japanese patients were diagnosed with EPC at the Department of Dermatology in the Hachioji Medical Center of Tokyo Medical University. Patient data, including clinical manifestations, histopathological findings, immunohistochemical results, treatment method, and clinical course were collected and documented. Results: The mean age of the patients (6 males and 2 females) was 72.6 years. The duration of the lesions ranged from 4 months to 5 years (mean: 3.5 years). All of the lesions clinically presented with erosive reddish nodules (mean size: $39.0 \mathrm{~mm}$ ). Initial $\mathrm{CT}$ imaging revealed that 1 case had multiple distant metastases. Surgical resection was performed for all primary lesions and follow-up observations were available in all cases (mean: 10.9 months). One case with distal metastases underwent both radiation therapy and chemotherapy, but nevertheless succumbed to the disease. Conclusion: The EPC cases in our department presented a versatile clinical appearance and characteristic histopathological features.




\section{Introduction}

Eccrine porocarcinoma (EPC), first described by Pinkus and Mehregan in 1963 [1], is an uncommon sweat gland carcinoma and the malignant counterpart of eccrine poroma. Although some large case series of EPC have been published [2-11], the biological behavior of this entity has not been fully elucidated. Accurate diagnosis, optimal treatment, and prognosis of EPC are still challenging due to the paucity of data concerning this condition. The aim of this study is to report the clinical and pathological features of EPC and to contribute to the body of information currently available to dermatologists.

\section{Patients and Methods}

Between 2003 and 2013, 8 patients were diagnosed with EPC at the Department of Dermatology in the Hachioji Medical Center of Tokyo Medical University. The clinical characteristics of the neoplasm, such as color, shape, and size, were evaluated and recorded by expert dermatologists. Resected specimens were fixed with $10 \%$ buffered formalin, and paraffin-embedded histological sections were stained with hematoxylin-eosin (HE). In addition to the routine microscopic observation, the following histopathological prognostic factors described by Robson et al. [7] were evaluated in each specimen: (1) lymphovascular invasion; (2) depth of invasion measured from the granular layer or ulcerated surface of the neoplasm to the deepest site of invasion; (3) number of mitoses per 10 high-power fields (HPF) by $\times 40$ objective and $\times 10$ eye space, and (4) growth pattern of the neoplastic margin. Moreover, immunohistochemical examinations using CAM5.2 (BD Biosciences, San Jose, Calif., USA), epithelial membrane antigen (EMA; DakoCytomation, Glostrup, Denmark), and carcinoembryonic antigen (CEA; DakoCytomation) were performed.

\section{Results}

\section{Clinical Findings}

The preoperative clinical features of the 8 cases, 6 Japanese males and 2 Japanese females, are shown in table 1 . The mean age was 72.6 years (range: $47-98$ years). Two of the lesions had developed on the head, and 1 each on the back, arm, forearm, buttock, thigh, and lower leg. The duration of the lesions ranged from 4 months to 5 years (mean: 3.5 years). The mean size of the primary lesion was $39 \mathrm{~mm}$ (range: 18-70 mm). All cases presented reddish nodules displaying an erosive or ulcerated surface, while 5 cases displayed a pedunculated appearance (fig. 1a, b). The results of the initial CT imaging demonstrated multiple metastatic lesions to the mediastinum lymph node, and distant metastases to the brain, liver, and lung in only 1 case with the primary lesion on the left arm.

\section{Histopathological Findings}

The histopathological and immunohistochemical features of the primary lesions are documented in table 2. In all cases, the malignant neoplastic lesions extended from the epidermis to the dermis (fig. 2a), and were composed of large, basaloid and atypical neoplastic cells with hyperchromatic nuclei and some mitotic figures (fig. 2b). Duct-like structures with eosinophilic cuticular borders were detected in all of the cases (fig. 2a).

Previously described prognostic factors were evaluated as follows: vascular invasion was detected in 1 case deep within the lesion (fig. 2c). The depth of invasion ranged from 0.7 
to $20.0 \mathrm{~mm}$ (mean: $8.2 \mathrm{~mm}$ ). The number of mitoses per $10 \mathrm{HPF}$ varied from 0.6 to 12.3 (mean: 4.1). The growth patterns of the neoplastic margin were classified into 2 groups: an 'infiltrative' growth pattern was seen in 5 cases (fig. 2d), while a 'pushing' pattern was seen in 3 cases (fig. 2e).

Immunohistochemical examinations revealed that EMA was positive in all 8 cases, and CAM5. 2 was positive in 5 cases. CEA, mostly stained in the duct-like structures, was positive in 6 cases.

\section{Treatment and Clinical Course}

The details of the treatment and clinical course from the follow-up observation are summarized in table 1. Surgical resection was performed in all of the cases. None of the resected specimens presented malignant cells on the surgical margin. As adjuvant therapy, local radiation therapy was administered in 2 cases presenting a narrow vertical margin. Chemotherapy consisting of 6 courses of docetaxel treatment plus 3 courses of docetaxel and cisplatin were administrated to the patient suffering from multiple metastases.

Follow-up observation was conducted in all of the cases. The duration of the observation ranged from 1 month to 2 years (mean: 10.9 months). During the follow-up period, 7 out of the 8 cases, including the patient who received 50 Gy of radiation therapy, showed neither local recurrence nor metastasis. Among them, the oldest case (98 years old) died of heart failure 3 months after the resection. The case with multiple metastases was treated with 21 Gy of radiation therapy and chemotherapy as described above, but nevertheless failed to show a clinical response; the patient experienced local recurrence on the periphery of the skin graft (fig. 3a) and multiple bone metastases afterwards. Although the recurrent lesion was surgically resected again, the histopathology demonstrated intradermal proliferation of EPC cells (fig. 3b), and the patient succumbed to his condition 8 months after the resection.

Because the prognostic outcomes such as local recurrence, lymph node metastasis, and distant metastasis were seen in only 1 case, a statistical analysis of the patients' prognosis and clinical or histopathological variables could not be performed.

\section{Discussion}

In previous publications, some authors described EPC as a biologically aggressive neoplasm with a high rate of recurrence and metastasis [2]. In contrast, the largest case series by Robson et al. [7] (69 EPC cases) reported that local recurrence, lymph node metastasis, and distant metastasis were confined to 17,20 , and $10 \%$ of the cases, respectively, and concluded that aggressive behavior may be the exception. Similarly, other authors reported indolent biological behavior in EPC $[3,5,6,8]$. In the present case series, only 1 out of the 8 cases $(12.5 \%)$ presented a number of unfavorable clinical events including local recurrence, lymph node metastases, distant metastases, and mortality, which appeared to be consistent with the above-mentioned reports.

Robson et al. [7] also suggested the 4 histopathological findings as prognostic factors in EPC patients. Lymphovascular invasion was related to death. A depth of invasion greater than $7 \mathrm{~mm}$ or more than 14 mitoses per $10 \mathrm{HPF}$ were associated with death or lymph node involvement. The infiltrative growth pattern was predictive of local recurrence. In the present case series, 1 aggressive case (Case 4) displayed 3 of these prognostic factors. The remaining cases also displayed the depth of invasion (Cases 3,6, and 7) and infiltrating growth pattern (Case 1, 6, 7, and 8) considered to be predictive of recurrence or metastasis, but nevertheless showed neither of these outcomes. These inconsistent prognostic results 
were also reported in a retrospective study by Shiohara et al. [9], who observed that the number of mitoses and depth of invasion were not important prognostic factors. However, it should be noted that the present case series treated a small number of cases with a short period of follow-up observation, facts which might be responsible for the inconsistency of the prognostic results.

\section{Conclusion}

In this paper, we reported 8 Japanese cases of EPC. Only 1 case resulted in a local recurrence, lymph node metastases, distant metastases, and death. The prognosis of EPC may not be as dismal as previously believed; however, this entity occasionally shows aggressive behavior. In spite of the prognostic factors outlined in previous reports, an accurate prediction of the outcomes of EPC still poses a challenge for the dermatologist. Early detection and complete excision can minimize the mortality rate in EPC.

\section{References}

1 Pinkus H, Mehregan AH: Epidermotropic eccrine carcinoma. Arch Dermatol 1963;88:597-606.

-2 Shaw M, McKee PH, Lowe D, Black MM: Malignant eccrine poroma: a study of twenty-seven cases. Br J Dermatol 1982;107:675-680.

3 Mehregan AH, Hashimoto K, Rahbari H: Eccrine adenocarcinoma. A clinicopathologic study of 35 cases. Arch Dermatol 1983;119:104-114.

-4 Wollina U, Castelli E, Rulke D: Immunohistochemistry of eccrine poroma and porocarcinoma - more than acrosyringeal tumors? Recent Results Cancer Res 1995;139:303-316.

5 Lozano Orella JA, Valcayo Peñalba A, San Juan CC, Vives Nadal R, Castro Morrondo J, Tuñon Alvarez T: Eccrine porocarcinoma. Report of nine cases. Dermatol Surg 1997;23:925-928.

-6 Urso C, Bondi R, Paglierani M, Salvadori A, Anichini C, Giannini A: Carcinomas of sweat glands: report of 60 cases. Arch Pathol Lab Med 2001;125:498-505.

7 Robson A, Greene J, Ansari N, Kim B, Seed PT, McKee PH, Calonje E: Eccrine porocarcinoma (malignant eccrine poroma): a clinicopathologic study of 69 cases. Am J Surg Pathol 2001;25:710-720.

-8 Perna C, Cuevas J, Jiménez-Heffernan JA, Hardisson D, Contreras F: Eccrine porocarcinoma (malignant eccrine poroma). Am J Surg Pathol 2002;26:272-274.

-9 Shiohara J, Koga H, Uhara H, Takata M, Saida T: Eccrine porocarcinoma: clinical and pathological studies of 12 cases. J Dermatol 2007;34:516-522.

10 Mahomed F, Blok J, Grayson W: The squamous variant of eccrine porocarcinoma: a clinicopathological study of 21 cases. J Clin Pathol 2008;61:361-365.

11 Luz Mde A, Ogata DC, Montenegro MF, Biasi LJ, Ribeiro LC: Eccrine porocarcinoma (malignant eccrine poroma): a series of eight challenging cases. Clinics (Sao Paulo) 2010;65:739-742. 


\section{Case Reports in Dermatology}

\begin{tabular}{l|l}
\hline Case Rep Dermatol 2013;5:259-266 \\
\hline DOI: $10.1159 / 000355606$ & $\begin{array}{l}\text { (c) 2013 S. Karger AG, Basel } \\
\text { www.karger.com/cde }\end{array}$ \\
\hline
\end{tabular}

Kurashige et al.: Eccrine Porocarcinoma: Clinical and Pathological Report of Eight Cases

Table 1. Clinical findings, treatment, and clinical course

\begin{tabular}{|c|c|c|c|c|c|c|c|c|c|c|c|c|c|c|}
\hline \multirow[t]{2}{*}{ Case } & \multicolumn{7}{|c|}{ Clinical findings } & \multicolumn{3}{|c|}{ Treatment } & \multicolumn{4}{|c|}{ Clinical course } \\
\hline & $\begin{array}{l}\text { age, } \\
\text { years }\end{array}$ & sex & site & $\begin{array}{l}\text { dura- } \\
\text { tion, } \\
\text { years }\end{array}$ & $\begin{array}{l}\text { size, } \\
\mathrm{mm}\end{array}$ & $\begin{array}{l}\text { lymph node } \\
\text { metastasis }\end{array}$ & $\begin{array}{l}\text { distant } \\
\text { metasta- } \\
\text { sis }\end{array}$ & $\begin{array}{l}\text { surgical } \\
\text { resec- } \\
\text { tion }\end{array}$ & $\begin{array}{l}\text { radiation } \\
\text { therapy }\end{array}$ & $\begin{array}{l}\text { chemo- } \\
\text { therapy }\end{array}$ & $\begin{array}{l}\text { follow-up } \\
\text { period, } \\
\text { months }\end{array}$ & $\begin{array}{l}\text { local } \\
\text { recur- } \\
\text { rence }\end{array}$ & $\begin{array}{l}\text { post- } \\
\text { operative } \\
\text { metastasis }\end{array}$ & $\begin{array}{l}\text { cause of } \\
\text { death }\end{array}$ \\
\hline 1 & 77 & $\mathrm{~F}$ & right buttock & 5 & 20 & - & - & + & - & - & 7 & - & - & - \\
\hline 2 & 83 & M & head & 1 & 18 & - & - & + & - & - & 7 & - & - & - \\
\hline 3 & 79 & $\mathrm{~F}$ & left lower leg & 0.33 & 32 & - & - & + & - & - & 1 & - & - & - \\
\hline 4 & 50 & $\mathrm{M}$ & left arm & 0.58 & 80 & + & + & + & $21 \mathrm{~Gy}$ & $\begin{array}{l}\text { docetaxel + } \\
\text { cisplatin }\end{array}$ & 8 & + & bones & EPC \\
\hline 5 & 80 & M & head & 1 & 35 & - & - & + & - & - & 8 & - & - & - \\
\hline 6 & 47 & $\mathrm{M}$ & right thigh & 5 & 30 & - & - & + & $50 \mathrm{~Gy}$ & - & 48 & - & - & - \\
\hline 7 & 98 & M & right forearm & 5 & 70 & - & - & + & - & - & 3 & - & - & $\begin{array}{l}\text { heart } \\
\text { failure }\end{array}$ \\
\hline 8 & 67 & M & back & 2 & 30 & - & - & + & - & - & 5 & - & - & - \\
\hline
\end{tabular}

Table 2. Histopathological and immunohistochemical findings

\begin{tabular}{|c|c|c|c|c|c|c|c|c|c|c|c|}
\hline \multirow[t]{2}{*}{ Case } & \multirow{2}{*}{$\begin{array}{l}\text { Atypical } \\
\text { poroid cell }\end{array}$} & \multirow{2}{*}{$\begin{array}{l}\text { Duct } \\
\text { formation }\end{array}$} & \multirow{2}{*}{$\begin{array}{l}\text { Intra- } \\
\text { epidermal } \\
\text { lesion }\end{array}$} & \multirow{2}{*}{$\begin{array}{l}\text { Poroma-like } \\
\text { components }\end{array}$} & \multirow{2}{*}{$\begin{array}{l}\text { Vascular } \\
\text { invasion }\end{array}$} & \multirow{2}{*}{$\begin{array}{l}\text { Depth of } \\
\text { invasion, } \\
\mathrm{mm}\end{array}$} & \multirow{2}{*}{$\begin{array}{l}\text { Mitoses, } \\
\text { n/10 HPF }\end{array}$} & \multirow{2}{*}{$\begin{array}{l}\text { Growth } \\
\text { pattern }\end{array}$} & \multicolumn{3}{|c|}{ Immunohistochemistry } \\
\hline & & & & & & & & & CAM5.2 & EMA & CEA \\
\hline 1 & + & + & + & - & - & 2.2 & 1.8 & infiltrative & - & + & + \\
\hline 2 & + & + & - & - & - & 5.7 & 0.6 & pushing & + & + & + \\
\hline 3 & + & + & - & + & - & 9.3 & 0.9 & pushing & - & + & + \\
\hline 4 & + & + & - & - & + & 8.0 & 12.3 & infiltrative & + & + & + \\
\hline 5 & + & + & - & - & - & 5.9 & 4.4 & pushing & - & + & + \\
\hline 6 & + & + & - & - & - & 13.6 & 1.3 & infiltrative & + & + & + \\
\hline 7 & + & + & - & - & - & 20.0 & 8.7 & infiltrative & + & + & - \\
\hline 8 & + & + & - & + & - & 0.7 & 2.8 & infiltrative & + & + & - \\
\hline
\end{tabular}




\section{Case Reports in Dermatology}

\section{Case Rep Dermatol 2013;5:259-266}

DOI: $10.1159 / 000355606$

Kurashige et al.: Eccrine Porocarcinoma: Clinical and Pathological Report of Eight Cases
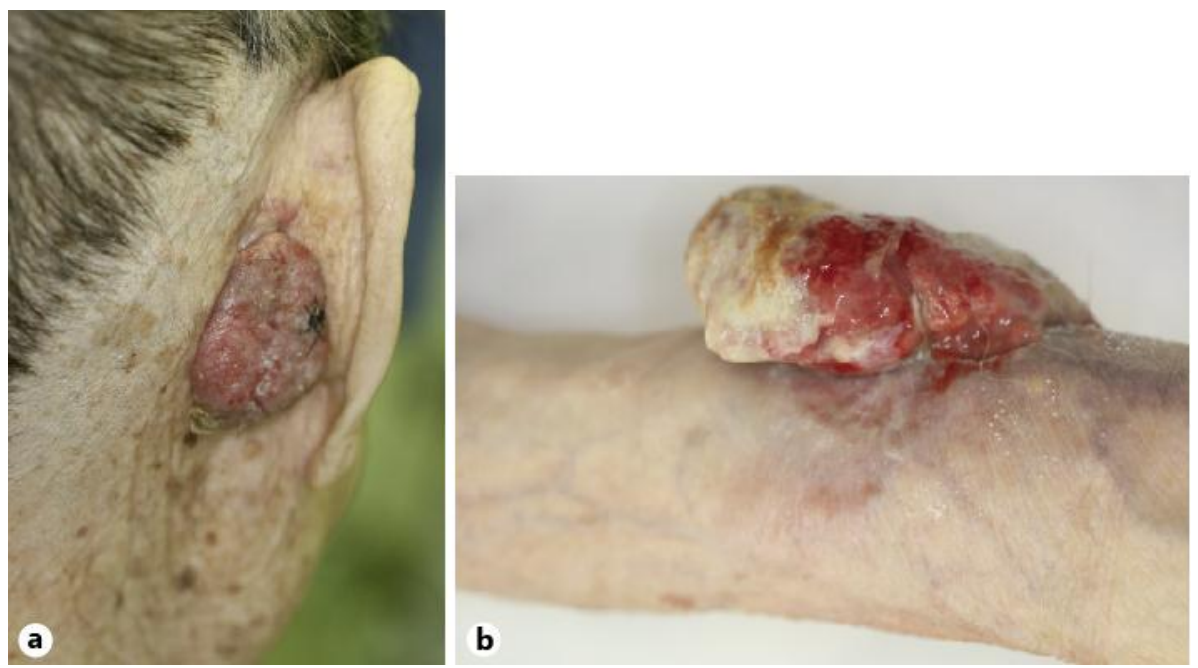

Fig. 1. Clinical photographs of EPC. a Pedunculated reddish nodule with erosive surface (Case 5). b Large, ulcerated nodule (Case 7). 

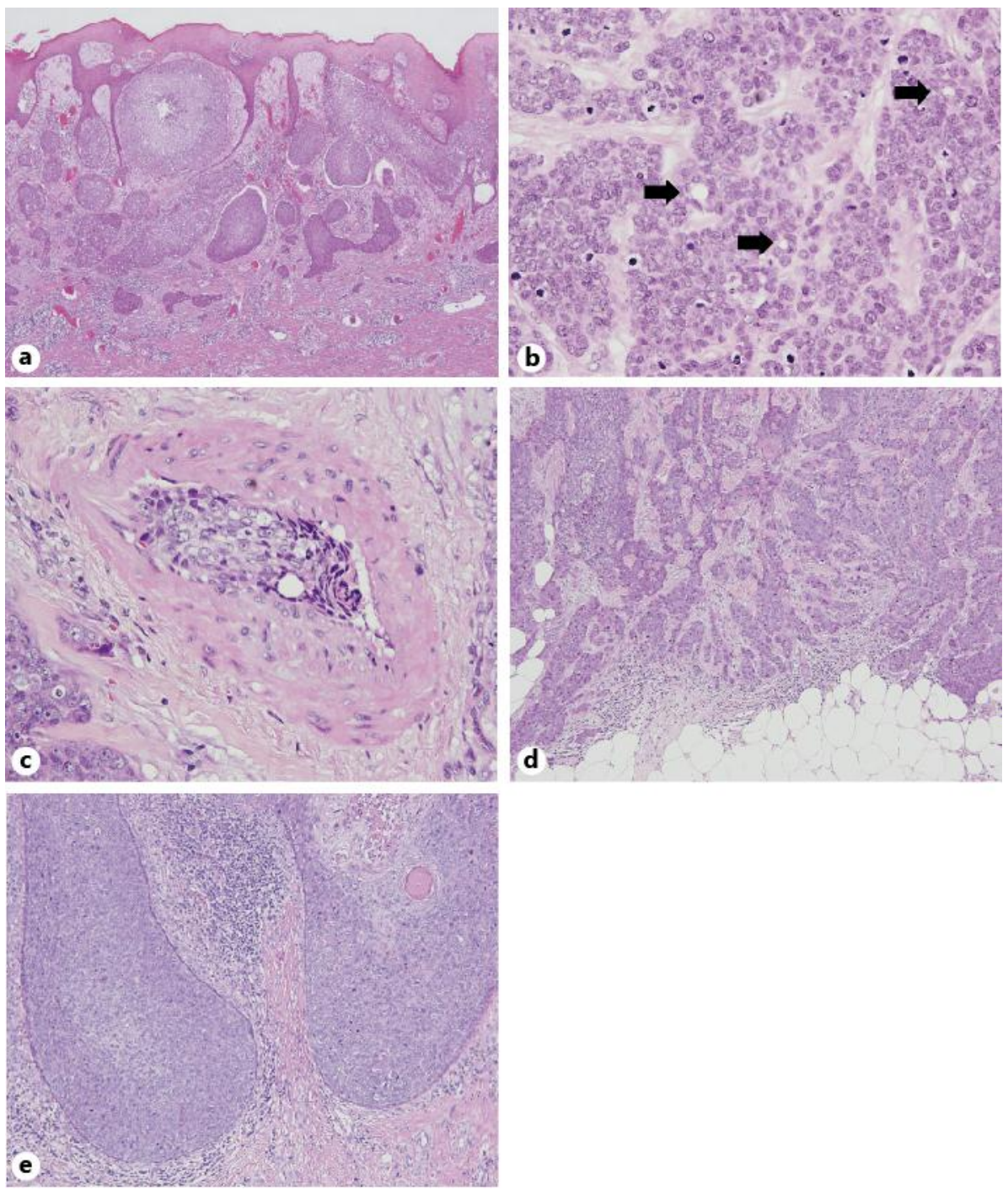

Fig. 2. Histopathology of the EPC cases. a EPC components extend from the epidermis to the dermis (Case 1; HE; ×40). b Atypical neoplastic cells with hyperchromatic nuclei and some mitotic figures were seen. Arrows indicate the duct-like structures with eosinophilic cuticular borders (Case 7; HE; ×400). c Vascular invasion was seen deep within the lesion (Case 4; HE; $\times 400$ ). d 'Infiltrative' growth pattern (Case 4; HE; $\times 100$ ). e 'Pushing' growth pattern (Case 5; HE; ×100). 
Kurashige et al.: Eccrine Porocarcinoma: Clinical and Pathological Report of Eight Cases
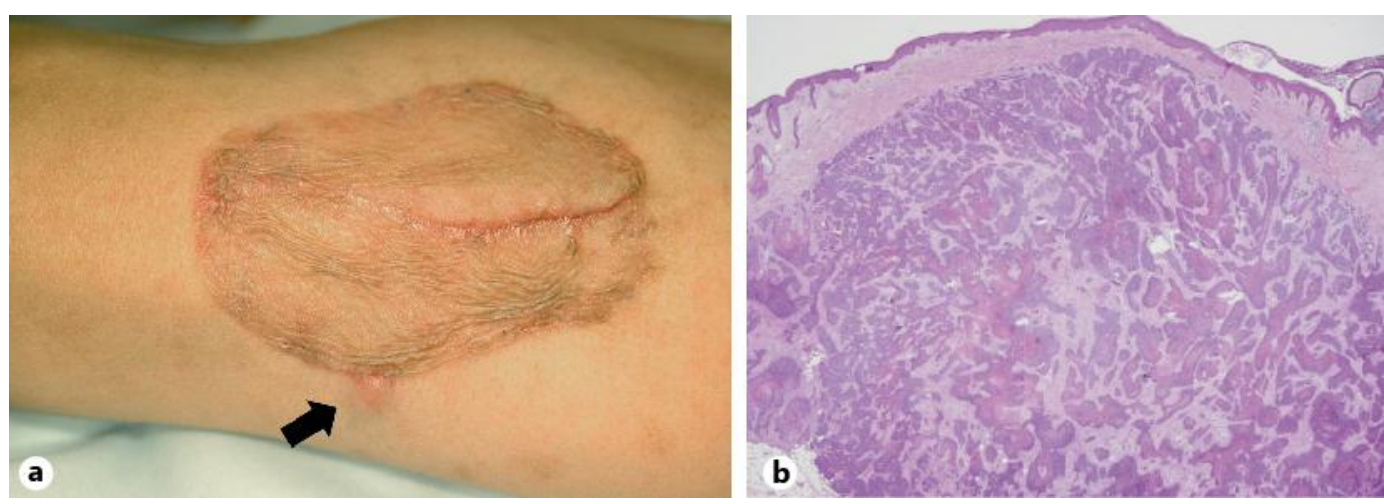

Fig. 3. Clinical and histopathological features illustrating the local recurrent lesion. a Clinical photograph of the subcutaneous induration on the periphery of the skin graft (arrow: Case 4). b Histopathology of the recurrent lesion demonstrated intradermal proliferation of EPC cells (Case 4; HE; ×20). 